$0.892 \quad 7 / 11$

\title{
ON THE GEOPHYSICAL AND GEOCHEMICAL MODELS OF THE EARTH'S SHIELDS AND RIFT ZONES
}

D. H. Chung

February 25, 1977

Prepared for U.S. Energy Research \& Development Administration under contract No. W-7405-Eng-48
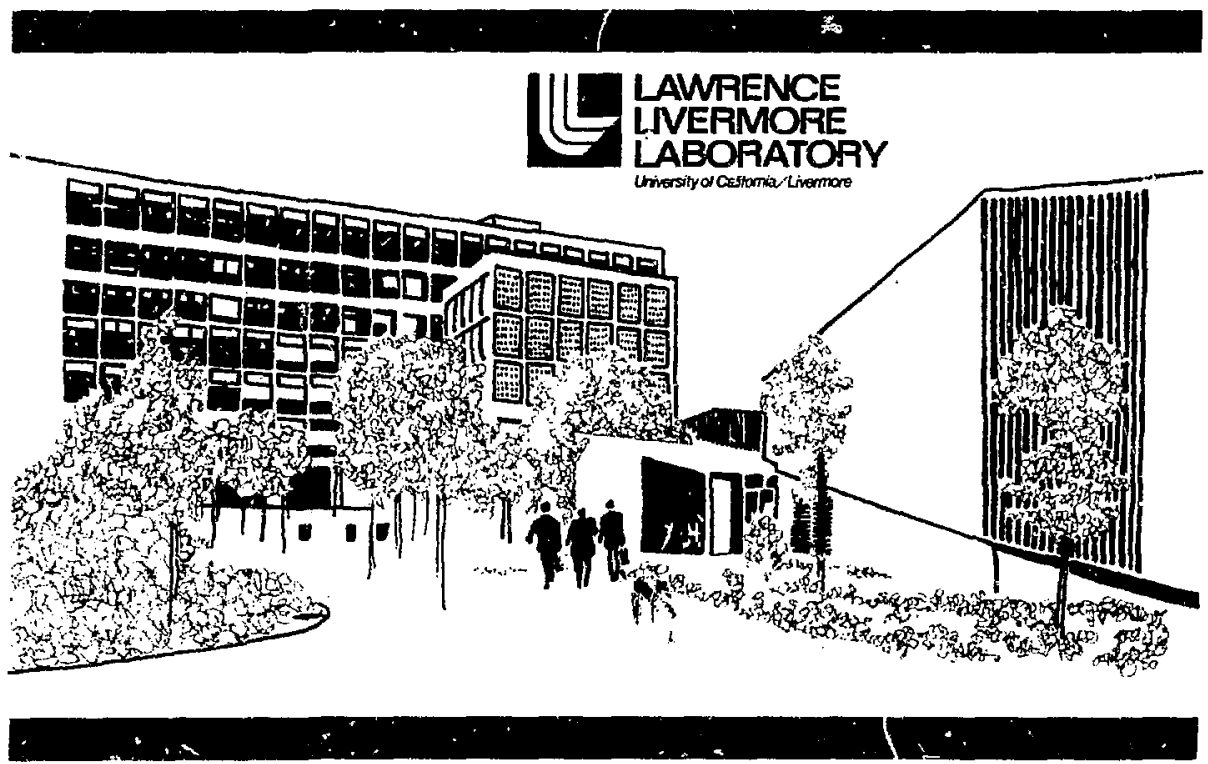


\section{NOTICE}

This repost wa prepared an account of work apunsored by the United States Government. Neither the United States nor the United States Energy Roserch * Dexelopment Adminitation, nor any of their employses, nor any of their contrecton, wboontractors, or their employet, mukes any warranty, expres $\alpha$

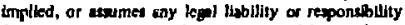
for the necuncy. completenes os uxefulness of any informaliun, spparatus, product or pre $\cdot$ diselosed, or epresents that its une would not infrinfe rivately-owned sughts.

\section{NOTICE}

Reference to a company or product nome does not Imply approval or recommendation of the product by the Univervity of Callfornia or the U.S. Energy Reseerch a Development Admitutration to the exclusion of ohen that may be suitable.

Printed in the United States of America Arailable from

National Technical Information Service

U.S. Department of Commerce

5285 Port Royal Road

Springfield, VA 22161

Price: Printed Copy $\$$; Microflche $\$ 3.00$

\begin{tabular}{|c|c|c|c|}
\hline Pego Rang: & $\begin{array}{c}\text { Dombtis } \\
\text { Price }\end{array}$ & Pav Ranot & $\begin{array}{c}\text { Dormute } \\
\text { Price }\end{array}$ \\
\hline $001-025$ & $\$ 3.50$ & $326-350$ & 10.00 \\
\hline $020^{\circ}-050$ & 4.00 & $351-375$ & 10.50 \\
\hline $051-075$ & 4.50 & $376-400$ & 10.75 \\
\hline $076-100$ & 5.00 & $40 t-425$ & 11.00 \\
\hline $101-125$ & 5.50 & $426-450$ & 11.75 \\
\hline $126-150$ & 6.00 & $451-475$ & 12.00 \\
\hline $151-175$ & 6.75 & $476-500$ & 12.50 \\
\hline $176-200$ & 7.50 & $501-525$ & 12.75 \\
\hline $201-215$ & 7.75 & $526-550$ & 13.00 \\
\hline $226-250$ & 8.00 & $551-575$ & 13.50 \\
\hline $251-275$ & 9.00 & $5 / 6-600$ & 13.75 \\
\hline $276-300$ & 9.25 & 601-up & $\bullet$ \\
\hline $301-325$ & 9.75 & & \\
\hline
\end{tabular}

"Add 52,50 fot each addilioral 100 pare inerement fram 601 to 1,000 parter add \$4s0 for each additional to0 page incrennent oret 1,000 pates. 


\section{㢟}

\section{LAWRENCE LIVERMORE LABORATORY}

University of Catomia Livormom.Calitornia 94550

UCRL-52236

\section{ON THE GEOPHYSICAL AND GEOCHEMICAL MODELS OF THE EARTH'S SHIELDS AND RIFT ZONES}

D. H. Chung

MS. Date: February 25, 1977

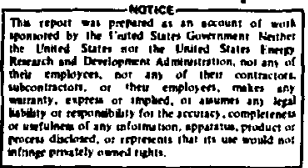

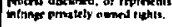

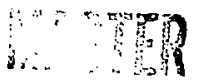




\title{
ON THE GEOPHYSICAL AND GEOCHEMICAL MODELS OF THE EARTH'S SHIELDS AND RIFT ZONES
}

\begin{abstract}
This report sumriatizes a collection, synthesis of, and speculation on, the geophysical and geochemical models of the Earth's stable shields and rift zones. There are two basic crustal types, continental and oceanic, and two basic mantle types, stable and unstable. The crustal types are distinguished by their thickness of crust, and the two mantle types are distinguished by their stabliticy and upper mantle velocities end travel-time residuals. The stable mantle is characterized by relatively high $P_{n}$ and $S_{n}$ velosities and the frequent absence of geophysical evidences for low velocity zone and the unstable mantle by low $P_{n}$ and $S_{n}$ velocities and a pronounced low velocity zone in the upper mantle. Both the crust and upper mantle play a strongly interactive role with surface geological phenomena ranging from the occurrence of mountalns, ocean trenches, oceanic and

continental rifts to geographic distributions of earthquakes, faults, and volcanous. On the composicton of the mantle, there is little doubt regarding the view that olivine constitutes a sajor fraction of the mineralogy of the Earth's upper mantle. To simulate the elasticity and composition of the Earth's lower crust and upper mantle, a systamatic study of the elastictiy and equation-of-state properties of such macerials as per1dotites, eclogites, pyroxenites, amphibolites, and various gabbros and basalts is needed. Also needed are measurements of attenuation of acoustic waves at seismic frequencies In these solids and partially molten peridotites and in olivine singlecrystals, because such data are necessary to determine the nature of phenomena responsible for the existence of a low velocity zone in the upper mantle.
\end{abstract}

\section{Introduction}

In the Earth, the propagation paths of selsmic waves differ considerably from region to region due to varlations of the structur: and possibly the physical state and composition of the Earth's crust and upper mantle. Direct methods have to be devised to Improve the present precision and rellability of selsmic yields by detafled investigations of the regional 
variations of the "fine" structure, composition, and physical state of the Earth's crust and upper mantle. As indicated by the recent progress In observational seismology, the subject is basic to our understanding of all the seismic signals arriving at receiving stations.

As a part of the LLI Seismic Monitoring Research Program, this communication describes my collection, synthesis of, and speculation on, the geophysica! and geoct rmical models of the Earth's stable shield areas and rift zones. Understanding of these tectonic reglonal fatures of the Earth is of practical concern to the LLL Seismic Monitoring Research Program (as well as other programs dealing with seismic yleld verification of an explosion) because certain test sites (US and French) are located within rift zones or hot spots surrounded by stable shleld areas. This research is directly related to improving our ability to estimate the yleld of an explosion reliably.

\section{Shields and Rift Zones: A Generalized Tectonic Classification}

A generallzed tectonic classification ard the geophysical properties of the three most common crustal types (shields, rift zones, and for comparison, ocean basins) are presented in Table 1. In it, I used such parameters as crustal thickness, $P_{n}$ and $S_{n}$ velocities, travel-time residuals for $P-$ and S-waves, tectonic characteristics, heat flow and Bouguer gravity anomalies, sediment thickness, and water depth (in accordance with Brune $^{1}$ ).

Shields, within the context of plate tectonics, are very stable parts of the continents. Earthquake activities are low because few yolcanoes have developed in these areas in recent earth history. The surface features Include exposed deep metamorphic and plutonic rocks created through years of erosion processes. There are no thick sedimentary deposits younger than those of the Precambrian time. The typical shield structure has a crustal thickness of about $35 \mathrm{~km}$, and the $P$ - and S-wave velocities Increase with depth from about 6.1 and 4.3 $\mathrm{km} / \mathrm{sec}$, respectively', to about 6.8 and $4.6 \mathrm{kr} / \mathrm{sec}$ at a depth of $30 \mathrm{~km}$ or so. The $P_{n}$ and $s_{n}$ velocities are generally higher than in any other tectonic regions, typically 8.1 and $4.7 \mathrm{~km} / \mathrm{sec}$, respectively. Heat flow values are generally 1 ow and seldom exceed $1.0 \mathrm{HFU}\left(1 \mathrm{HFJ}=1 \mu \mathrm{cal} / \mathrm{cm}^{2}\right.$ 
Table 1. Tectonic classification and geophysical properties of stable shields, rift zones, and ocean basins of the Earth's surface.

\begin{tabular}{|c|c|c|c|}
\hline $\begin{array}{l}\text { Generalized } \\
\text { crustal type }\end{array}$ & Shields & Rift zones & Ocean basins \\
\hline $\begin{array}{l}\text { Tectonic } \\
\text { characteristic }\end{array}$ & very stable & unstable & very stable \\
\hline $\begin{array}{l}\text { Crustal } \\
\text { trickness (km) }\end{array}$ & $30-38$ & $\sim 30$ & $\sim 11$ \\
\hline$P_{n}(k m / s e c)$ & $8.1-8.3$ & $7.4-7.8$ & $7.8-9.2$ \\
\hline $\mathrm{s}_{\mathrm{n}}(\mathrm{km} / \mathrm{sec})$ & $4.69-4.87$ & $4.51-4.60$ & $4.70-4.74$ \\
\hline $\begin{array}{l}\text { Travel time } \\
\text { residuals (sec) } \\
\text { for P-waves }\end{array}$ & $n-1$ & $2+1$ & $2-1$ \\
\hline $\begin{array}{l}\text { Travel time } \\
\text { residuals (sec) } \\
\text { for S-waves }\end{array}$ & $2-4$ & $2+4$ & $2-4$ \\
\hline Heat flow (HFU) & $0.7-1.2$ & $1.7-2.5$ & 21.3 \\
\hline $\begin{array}{l}\text { Bouguer gravity } \\
\text { anomaly (mgal) }\end{array}$ & $-10--40$ & $-200--300$ & $+250-+350$ \\
\hline $\begin{array}{l}\text { Surface geologic } \\
\text { features }\end{array}$ & $\begin{array}{l}\text { Little or no } \\
\text { sediment, exposed } \\
\text { batholitic rocks } \\
\text { of Precambrian } \\
\text { age. } \\
\text { Very of ten, moder- } \\
\text { ate thicknesses } \\
\text { of post- } \\
\text { Precembrian sedi- } \\
\text { ments visible. }\end{array}$ & $\begin{array}{l}\text { More recent normal } \\
\text { faulting, volcan- } \\
\text { ism, and intru- } \\
\text { sion; high mean } \\
\text { elevation; often } \\
\text { rapid recent up- } \\
\text { lifting visible. }\end{array}$ & $\begin{array}{l}\text { Very thin sedi- } \\
\text { ments overlying } \\
\text { basalts, Ilnear } \\
\text { magnetic anom- } \\
\text { altes, no visi- } \\
\text { ble thick } \\
\text { Paleozoic } \\
\text { sediments. }\end{array}$ \\
\hline
\end{tabular}

sec). The Bouguer gravity anomaly is moderately negative $(-10$ to about -40 mgal at most).

The crustal type under rift zones includes such tectonically unstable areas as the Basin and Range Province, the Baikal Lake region, the Hoggar area, and the East Pacific Rise regions to name a few, and is characterized by recent normal faulting, volcanism, and intrusion that have resulted in a series of vistble basins and ranges with a high mean elevation. The thickness of sediment varies from region to region, but is usually comprised of eroded volcanic materials. 
The crustal thickness ranges from 20 to $30 \mathrm{~km}$ In most rift zones, except for Alpine regions where high mountains were created by rapid uplift. The $P_{n}$ and $S_{n}$ velocities are generally low, hut no sharp boundaries in the velocity structures are apparent. Heat flow is very high in general, of the order of 2 HFU. The gravity anomaly is highly negative, -200 to about -300 mgal. Trave1 time residuals for both $\mathrm{P}-$ and $\mathrm{S}$-waves are positive, as much as +1 sec for the $\mathrm{P}$-waves. These observations indicate highly atcenuating subsurface materials.

Ocean basing are regarded as stable parts of the Earth's crust overlain by water 4 to $5 \mathrm{~km}$ deep. The rocks are primarily basaltic overlaid with very thin sediment. The discovery in the late 1960's of remarkable linear magnetic anomalies paralleling oceanic ridges was a direct Indication of sea-floor spreading and continental drift. Recent progress in research ${ }^{2}$ of the oceanic basins indicate that a low-velocity crustal zone overlies a mantle with a P-wave velocity of about 7.8 to $8.0 \mathrm{kun} / \mathrm{sec}$. Major crustal changes occur Erom the ridge crest to the fiank; in particular, at or near the crest crustal $P$-wave velocities are $5.2,6.0$, and $7.0 \mathrm{~km} / \mathrm{sec}$, and $a$ low-velocity crustal zone overlies an anomalousiy low velocity mantle.
This wedge of low-velocity crust thins with increasing age, so that a transition Erom anomalous crust at the ridge crest to normal oceanlc crust occurs ovez a period of 5 to 6 million years. (Apparently, this low-velocity crustal wedge represents a magma reservolr with about $30 \%$ melt.) Mlost ocean basins are characterized by relatively high heat flow ( $1.3 \mathrm{HFU})$, and high positive Bouguer gravicy anomalies (t 250 to +350 mgal).

In summary, then, there are two basic crustal types: the continental and the oceanfic, and two basic mantle types: stable and unstable, exempl1fied by the Precambrian shield areas and rift zones, respectively. The crustal types are distinguished by the crustal thickness as summarized in Table 1. The two mancle types are distinguished by their stability and upper-mantle velocities and travel-time residuals, the stable mantle being characterized by relatively high $P_{n}$ and $S_{n}$ velocities and the frequent absence of geophysical evidences for low velocity zone and the unstable mantle being characterlzed by low $P_{n}$ and $S_{n}$ velocities and a pronounced low velocity zone in the upper mantle. It is therefore apparent that the crust and upper mantle are closely linked in a tectonic sense. 


\section{On the Constitution of the Upper Mantle: Olivine Models}

A perusal of the spectra of $P$-waves indicates that even explosions of very small magnitude are sig:ificantly richer in high frequencies (about 2 to $3 \mathrm{~Hz}$ ) than are most earthquakes. Regional variations of the structure, composition, and physical state of the Earth's upper mantle present problems and it seems that the attenuation (and hence the frequency transmission characteristics) of the Earth's upper mantle varies significantly trom place to place.

To what extent do we understand these regional variations and the constitution of the Earth's upper mantle? What are the most common rock types in these layers of the Earth's interior? What are the major mineral constituents in these rock types? These are among the more $f r c$. ontly asked questions by earth scientjsts. Numerous papers and books have been written; there are, however, as many variants of models as there are petrologists and geochemists.

What follows is my prejudice on the mineralogical composition of the average upper mantle, and it ts founded on geochemical and geophysical data supported by theories and experinents of Solid Earth Geophysics. It is my hope and expectation that by exposure to the many Interesting problems of our dynamic Solid Earth, experts in the LLL community will be enticed to engage in research on these topics. 3

Olivine has long been recognized as a major mineral constituent of the upper mantle. This conjecture, orlglnally based on inferences drawn from the study of stony meteorites, is supported strongly by the analysis of terrestrial rocks that appear to be either directly or indirectly derlved from upper mantle sources. Numerous studies have described inclusions of garnet peridotite and eclogite associated with kimberlites (Nixon et al., ${ }^{4}$ McGetchin and Silver, 5 Boyd and Nixon, ${ }^{6}$ and Boyd ${ }^{7}$ ). Abundent field, petrological, and geochemical data support the proposition that kimberlites originate well within the upper mantle. Eruptive basalts frequencly contain nodules which presumably represenc, at least in some cases, pleces of wall-rock torn from the volcanic vent or conduit (Harris et al. ${ }^{8}$ ). Generally, these nodules are ultramafic in composition (garnet and pyroxene peridotite, and rarely, eclogite) and thus contain a high percentage of olivine. In addition, alpine-peridotite ultramafic rock associations have frequently been described (Thayer, ${ }^{9}$ Wyllie, 10 Moores ${ }^{11}$ ), based on their tectonic setting and textural relations, as direct indicators of upfer-mantle 
composition. of particular relevance to our present interests is the fact that in all of the foregoting "mantlederived" materials, olivine is a domfnant mineral component. Based on the foregoing sources of infurmation, as well as on cosmic and solar elemental abundances, Kingwood 12,13 has derived a hypothetfcal composition for the primitive mantle and named it "pyrolite"; his pyrolfte model (3 parts alpine-peridotite to 1 part Hawailan basalt) contains $57 \mathrm{wt} \%$ (Mg, Fe) ${ }_{2} \mathrm{SiO}_{4}$ olivine.

The foregoing remarks serve to demonstrate the significance and importance of the mineral olivine to interpretations of the state and composition of the upper mantle. Most recent models of the physical properties for this region of Earth's interfor rely heavily on the relevant material properties of olivine. A number of years ago Bernal ${ }^{14}$ suggested that common olivine, which presumably occurs in the upper mantle, might transform into a splnel structure when an appropriate depth was reached. Later, Jeffreys ${ }^{15}$ and Birch ${ }^{16}$ expanded the olivine-spinel transition hypothesis as a qualitative explanation for the abnormally high $P$ - and S-wave velocity gradients in the transition zone of the mantle. Within the last 10 or 15 years, as a result of contrnuing improvements associated with both seismic recording technology and data analysis methods, considerable refinement has been possible in the description of the velocity structure of the upper mantle and the nature of the transition z:ıne. Perhaps the most significant iscuvery is the recognition of "finc-structure" within the transition zone. Several Investigators (Anderson and Toksöz, 17 Johnson, ${ }^{18}$ Archanbeau eㅗ 보. ${ }^{19}$ ) recognized a few years ago thit the transltion zone is characterized by two abrupt discontinuitles in P-wave veloctty, which occur around $400 \mathrm{~km}$ and $650 \mathrm{~km}$. More recently, evidence has been presented (Helmberger and Wiggins, ${ }^{20}$ Wiggins and Helmberger, ${ }^{21}$ and Helmberger and Engen ${ }^{22}$ ) which suggests the presence of a third discontinutey in the region ef $500 \mathrm{~km}$. It is the $400 \mathrm{~km}$ discontinuicy, huw ever, that is directly relevant to the occurrence of olivine in the upper mantle. Extensive studies of the phase equilibria of ferromagnesian olfvines in the recent past have demonstrated almost unequivocally that the $400 \mathrm{~km}$ discontinuity in the upper mantle may be identified with the transformation of (Mg, Fe) ${ }_{2} \mathrm{SHO}_{4}$ olivine into a "modified" spinel structure, thus verifying Bernal's earlier supposition.

The work which was largely responsible for establishing the olivinespinel transformation as a valid explanation for the high-velocity 
gradiant of rlue transition zone was initiated by Ringwiod $s^{23}$ succossful synthesis ef the spinel polymorph of $\mathrm{Fr}_{2} \mathrm{SiO}_{4}$ at $600^{\circ} \mathrm{C}$, followed by Boyd and Fingland $s^{24}$ observations for Fe.sil ${ }_{4}$ at $1500^{\circ} \mathrm{C}$, and also in the phast stability expertments with

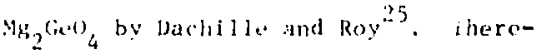
if ter, namirous studies were carried wet in arder to define In a cumpres lonsive and accurale manner the stability and phase relations of ferromague sian ollvint $\left(4,5, \mathrm{He}_{2} \mathrm{Sill}_{4}\right.$ at ligh lemperature and pressure. Direct experimental determination of the olivine-spinel transition was at first ristricted lo the iron-rich end of the solid solution system besaute of the prevailing I imitations of the available high-pressure apparatus. However, with the improvement of Bridgman anvil-tyne, high-pressure, high-temperature experimental devices, the equilibrium diagran for the olivine-spinel transformation was extended to within $20 \mathrm{~mol} \%$ of the $\mathrm{Mg}_{2} \mathrm{SiO}_{4}$ end member (Sclar and Carrison, 26 Ringwood and Major, 27 and Akimoto and Fujisawa ${ }^{28}$ ). It was noticed also by several authors (Ringwood and Major, 27,29 Akimoto and Ida, ${ }^{30} \mathrm{M}$, rimoto et $\mathrm{al},,^{31}$ and Noore and Smith ${ }^{32,33}$, that the highpressure modification on the forsterite end was that of an orthorhombic, "distorted" spinel structure, subsequent ly referred to as the ":phase." Presently, accurate data are avilibile which describe the olivinespinel phase relations and the nature and width of the two-phase repions al.ung isotherms of $900^{\circ}, 1000^{\circ}$, and $1200^{\circ} \mathrm{C}$ (Ringrond and Major, 29 and ikinuto and Fujisawa ${ }^{34}$ ). The results of such studics fndicate clearly, a ithough some experimental dicreparicies rematn (Akimuto ${ }^{35}$ ), that within the range of cenperature Iikely to occur in the upper mantle, forsterite-rich olivine transiorms intu a spinel or z-phase form at a pressure of around 120 kbar. In ierms of dept!, such a tri.usformation pressure is consistent with the major seismic discontinuity at about $400 \mathrm{~km}$ in the mantle.

Cunsidering the foregoing evidence of olivine as the dominant mineral corstituent of the upper mantle, attention was directed to the physical properties of ( $\mathrm{Mg}, \mathrm{Fe})_{2} \mathrm{SiO}_{4}$ and their relation to those physical characteristics which may be defined for the Earth's mantle from the analysis of geophysical observations. In a classic study, Anderson ${ }^{36}$ calculated the properties of the upper mantle using a pure olivine mode:.. His analysis rested on the phase equilibria data and elastic propert measurements for the ollvine solid solution series available at the time. More 
recently, several investigators (Birch, ${ }^{37}$ Chung, 38,39 Forsyth and Press, ${ }^{40}$ and Graham ${ }^{41}$ ) have also examined the properties of the upper nantle with regard to olivinedominant mineralogical models. Using more recent and complete sets of chemical and physical property data for olivine, these studies generally support the earlier speculations that the compressional and shear wave velocity profiles in the upper mantle may well be accounted for by a petrology that is characterized hy olivine as a major component. Figure 1 illustrates this point. What is shown is the density and the bulk sound velocities determined for various olivines with Press's $^{42}$ Monte Carlo solutions for the Earth's mantle. We find that the slopes of ollvine and olivinetransformed splnel with $F_{o} / F_{a}$ ratios of about $95 \mathrm{~F}_{0}$ to $85 \mathrm{~F}_{\mathrm{o}}$ are quite

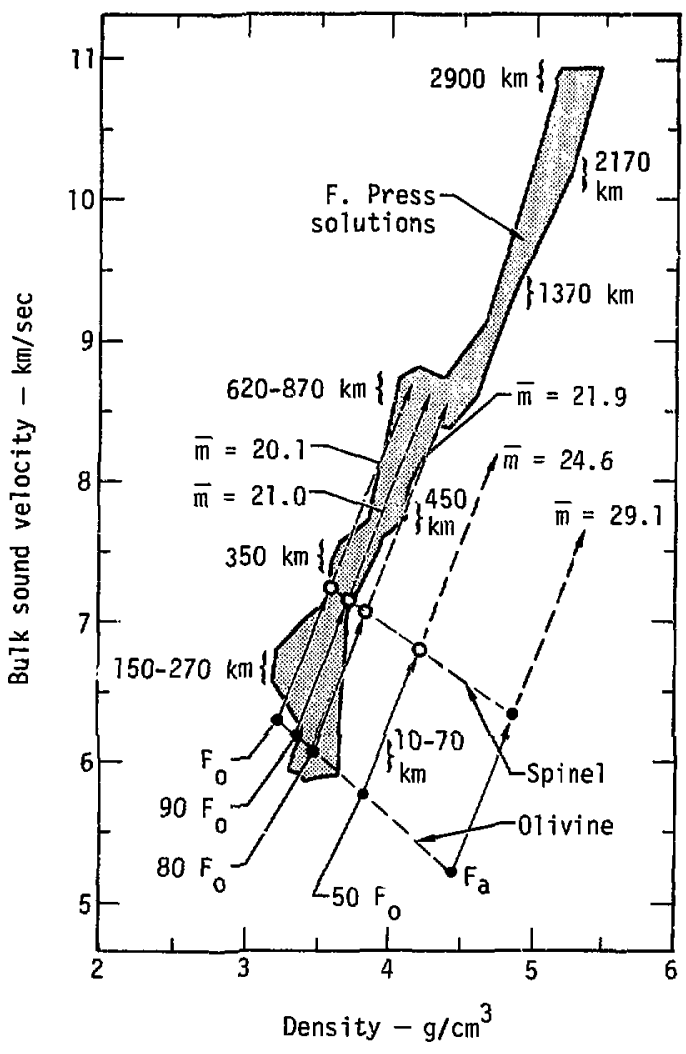

Fi.g. 1. Comparison of the laboratory bulk sound velocity-density relationship for olivine with $F$. Press's Monte Carlo successful solutions of the Earth data. 
similar to large numbers of the Monte Carlo successful solutions in the region 150 to $870 \mathrm{~km}$. Moreover, the most satjsfactory $\mathrm{Mg} / \mathrm{Fe}$ mol fraction is about 0.9 , a value that is consistent with the average composition of the olivines associated with alpine peridotites and xenollths and inclustons from kimberlites and basalt exuptives. Although recent investigators (Ahrens ${ }^{43,44}$ ) have constdered the possible effects and the necessity of additional mineral components (primarily ortho-pyroxene and pyrope garnet), there is 1ittle doubt regardIng the view that olfvine constitutes a major fraction of the mineralogy of the upper mantle.

What kind of perturbations in composition, phase, and the phystcal state do we need to account for shieldrift-ocean differences? The answers to this question await discovery on the frontier of contemporary Solid Earth Geophysics. During the Penrose Conference on The LithosphereAsthenosphere Boundaries in November 1975, it became apparent that we knos a great deal about the structure, composition, and the physical state of continents and very little about tectonics (including rift zones). In the oceans, the reverse is true. We need to know about both structure and tectonics of these areas and the implications of these on the development of the so-called "tectonosphere"
If we are to progress to the next step.

In an earlier comnuntcation (Chung ${ }^{45}$ ) I presented a view toward the possible structure and composition of a region such as the Basin and Range Province. And I concluded that the present structure of the Basin and Range Province is possibly a result of rifting in the western conterminous United States; under it lies a mixed structure of old crust and mantle materials. The low velocity zone under the Basin and Range Province would then be caused by downward chemical transition from the subMoho pyrolitfc mantle materfal into a plagioclase-rich ophiolitic cold oceanic crust and upper mantle materials) composition and associated melting, and then into a peridotitic composition at the bottom of the low velocity zone. This mixed material model, with partial melting, seems to explain the observed low $P_{n}$ and $S_{n}$ velocittes and low-seismic $Q$ in the region, as well as other geophysIcal observations.

The diagnosis of the composition and the physical state of the Earth's lower crust and upper mantle below the level of visual observation depends largely upon the correlation of selsmic velocities and their attenuation data with laborat y measurements of elasticity and attenuation and equation-of-state properties in 
samples of rock and mineral of known chemistry and mineralogy. The seismic structure does not, of course, depend upon the laboratory results; that is, the determination of wave velocities as a function of depth for a given locality depends only upon the seismic records, plus the judgment, skill, and general philosophy of the seismologist. Laboratory results are required for the translation of these numbers in terms of minerals or rocks, and for correlation with other physical properties. A systematic study of the elasticity and equation-of-state properties of such materfals as peridotites, eclogites, pyroxenftes, amphibolites, and various gabbros and basalts is needed to simulate the elasticity and composition of the Earth's lower crust and upper mantle. Measurements of attenuation of acoustic waves at seismic frequenctes under controlled high pressure and temperature in these solids and partially molten peridotites, and in olivine single crystals are needed to determine the nature of phenomena responsible for the existence of a low velocity zone in the upper mantle. 


\section{References}

1. J. N. Brune, in The Earth's Crust and lpper Mantie, P. J. Hart, Ed.

Geophys. Monogr. 13 (American Geophysical Union, Washington, D.C., J.969).

2. "The Nature of the Oceanic Crust," a spectal issue of $J$. Geophys. Res., 81, 4041-4421 (1976).

3. For enlightening discussions see C. L. Drake, Ed., Geodynomies: Frogress and Prospeets (American Geophysical Union, Washington, D.C., 1976), p. $238 \mathrm{ff}$.

4. P. H. Nixon, 0. von Knorring, and J. M. Rooke, Amer. Wineral., 48, 1090 (1963).

5. T. R. McGetchin and L. T. Silver, Amer. Mineral., 55, 1738 (1970).

6. F. R. Boyd and ?. H. Nixon, Camegie Inst. Washington Yearb., 12, 431 (1973).

7. F. R. Boyd, Geochim, Cosmochim. Acta, 37, 2533 (1973).

8. P. G. Harr1s, A. Reay, and I. G. Wh1te, J. Geophys. Res., 72, 6359 (1967).

9. T. P. Thayer, Int. Geoz. Congr. 21 Rep. Sesa. Norden., Pt. 13, 247 (1960).

10. P. J. Wyllie, Mineral. Soc. Amer. Spec. Pap.s 3, 3-32 (1970).

11. E. M. Moores, Earth Sci. Rev., 9, 241 (1973).

12. A. E. Ringwood, In Advances in Earth Sciences, P. M. Hurley, Ed. (MIT Press, Cambridge, Massachusetts, 1966).

13. A. E. Ringwood, Composition and Petrology of the Sarth's Mantie, (McGrawHill, New York, 1975).

14. J. D. Bernal, Observatory, 59, 268 (19.16).

15. H. Jeffreys, Mon. Notic. Roy. Astron. Soc., Geophys. Supp1., 4, 50 (1937).

16. F. Birch, Geophys. Res., 57, 227 (1952).

17. D. L. Anderson and M. N. Toksöz, J. Geophys, Res., 68, 3483 (1963).

18. L. Johnson, J. Geophys. Kes., 72, 6309 (1967).

19. C. B. Archambeau, E. A. Flinn, and D. G. Lambert, J. Geophys. Res., 74, 5825 (1969).

20. D. V. Helmberger and R. Wiggins, J. Geophys. Res., 76, 3229 (1971).

21. R. Wiggins and D. V. Helmberger, J. Geophys. Res., 78, 1870 (1973).

22. D. V. Helmberger and G. R. Engen, J. Geopitys. Res., 79, 4017 (1974). 
23. A. E. Ringwood, Geochim. Cosmochim. Acta, 15, 18 (1958).

24. F. R. Boyd and J. L. England, Carregil Inst. Washington Yearbi,, 59, 48 (1960).

25. F. Dachille and R. Roy, Amer. J. Sci., 258, 2.25 (1960).

26. C. B. Sclar and L. C. Carrison, Trans. Amer. Geophys. Union, abstract, 41, 207 (1966).

27. A. E. Ringwood and A. Major, Earth Planet. Sei. Lett., 1, 241 (1966).

28. S. Akimoto and H. Fujlsawa, Earth Planet. Sci. Lett., 1, 237 (1966).

29. A. E. Ringwond and A. Major, Phys. Earth Plonet. Interiors, 3, 89 (1970).

30. S. Akimoto and Y. Ida, Earth Planet. Sci. Lett., I, 358 (1966).

31. N. Morimoto, S. Akimoto, K. Koto, and M. Tokonam1, Science, 165, 586 (1969).

32. P. B. Moore and J. V. Smith, Nature, 221, 653 (1969).

33. P. B. Moore and J. V. Smith, Phys. Earth Planet. Interiors, 3, 166 (1970).

34. S. Akimoto and H. Fujisawa, J. Geophyo. Res., 73, 1467 (1968).

35. S. Akfmoto, Tectonophysias, 13, 151 (1972).

36. D. L. Anderson, Science, 157, 1165 (1967).

37. F. Birch, In The Earth's Crust and Upper Mantle, P. J. Hart, Ed. Geophys. Monogr. 13 (American Geophysical Union, Washington, D.C., 1959).

38. D. H. Chung, J. Geophys. Res., 75, 7353 (1970).

39. D. H. Chung, Geophys. J. Roy. Astron, Soc., 25, 511 (1971).

40. D. W. Forsyth and F. Press, J. Geophys. Res., 76, pp. 7663 and 7972 (1970).

41. E. K. Graham, Geophys. J. Roy. Astron. Soe., 20 (1970).

42. F. Press, in The Nature of Solid Earth, E. C. Robertson, Ed. (McGraw-Hill, New York, 1972).

43. T. J. Ahrens, Phys. Earth Planet. Interiors, 7, 167 (1973).

44. T. J. Ahrens, Rev. Geophys. Space Phys., 13, 335 (1975).

45. D. H. Chung, Teatonophysios (to be published, 1977). 